\title{
PENGEMBANGAN SISTEM INFORMASI PENGELOLAAN KEUANGAN BERBASIS KOMPUTER di SMK YAFALAH GINGGANGTANI
}

\author{
Fauzan \\ SMK Yafalah Ginggangtani \\ ifansyah661@gmail.com
}

\begin{abstract}
Abstrak
Tujuan penelitian: 1) Membuat sistem pengelolaan keuangan dengan menggunakan visual basic 6.0 untuk mempermudah identifikasi permasalahan yang berkaitan dengan pengelolaan keuangan sekolah. 2) Membuat terobosan baru yang lebih efektif dan lebih baik lagi untuk mewujudkannya ke dalam sistem aplikasi berbasis komputer secara sistematis, terstruktur, terarah, dan lengkap yang dapat digunakan dengan mudah dan cepat. 3) Dapat mengembangkan kualitas diri dan keilmuan yang didapat di perkuliahan, dan sebagai prasyarat menempuh skripsi S1 di Universitas Ivet pada Program Studi Pendidikan Informatika.

Jenis penelitian ini adalah penelitian research and development (R\&D), serta model pengembangan yang digunakan adalah model pengembangan Luther melalui 6 tahap yaitu: 1) Konsep. 2) Desain. 3) Pengumpulan data. 4) Pembuatan. 5) Testing. 6) Distribusi. Sumber data berupa data kuantitatif sebagai data pokok dan data kualitatif berupa saran dari responden sebagai data tambahan. Teknik pengumpulan data menggunakan metode angket dengan subyek penelitian kepala sekolah, bendahara sekolah, TU, dan guru di SMK Yafalah Ginggangtani.

Berdasarkan hasil penelitian menunjukan bahwa: 1) Pengujian functionality oleh ahli aplikasi adalah $100 \%$. 2) Pengujian functionality oleh ahli materi adalah $100 \%$. Hasil dari pengujian functionality kemuadian dikonversi kedalam skala kualitatif dan memperoleh hasil sangat baik. 3) Pengujian usability dari responden terhadap aplikasi keuangan ini adalah $83,37 \%$. Hasil pengujian ini kemudian dikonversi ke dalam sekala kualitatif, sehingga didapatkan hasil baik.
\end{abstract}

Kata kunci: Sistem Informasi, Pengelolaan Keuangan Sekolah.

\begin{abstract}
Research objectives: 1) Creating a financial management system using Visual Basic 6.0 to facilitate the identification of problems related to school financial management. 2) Making new breakthroughs that are more effective and better to realize it into a computer-based application system in a systematic, structured, directed, and complete manner that can be used easily and quickly. 3) Can develop the quality of self and knowledge obtained in lectures, and as a prerequisite to take a Bachelor thesis at Ivet University in the Informatics Education Study Program.

This type of research is research and development $(R \& D)$ research, and the development model used is Luther's development model through 6 stages, namely: 1) Concept. 2) Design. 3) Data collection. 4) Manufacture. 5) Testing. 6) Distribution. Sources of data in the form of quantitative data as basic data and qualitative data in the form of suggestions from respondents as additional data. Data collection techniques using a questionnaire method with research subjects school principals, school treasurers, $T U$, and teachers at SMK Yafalah Ginggangtani.

Based on the results of the study showed that: 1) Testing functionality by application experts is $100 \%$. 2) Testing functionality by material experts is 100\%. The results of the functionality testing were then converted to a qualitative scale and obtained excellent results. 3) The usability testing of respondents on this financial application is $83.37 \%$. The test results are then converted into a qualitative scale, so that good results are obtained.
\end{abstract}

Keywords: Information Systems, School Financial Management. 


\section{PENDAHULUAN}

Perkembangan teknologi yang sekarang ini berkembang sangat pesat menyebabkan banyak kalangan yang mencari alternatif pemecahan masalah di bidang teknologi sistem informasi. Penggunaan sistem komputer sebagai alat bantu penyelesaian pekerjaan di bidang teknologi sistem informasi semakin bertambah banyak dan berkembang di segala bidang. Komputer memiliki banyak keunggulan, hal itu dikarenakan komputer dapat diprogram untuk menyelesaikan masalah yang akan dipecahkan oleh pengguna.

Pada masa ini penggunaan teknologi informasi dan komunikasi merambah di segala bidang, misalnya dalam institusi pendidikan, selalu membutuhkan sistem untuk mengumpulkan, mengelola, menyimpan, melihat kembali dan menyalurkan informasi. Dimana komputer merupakan salah satu sarana yang dapat membantu dimana sistem informasi akan menghasilkan nilai lebih dari pada sebuah sistem yang diolah secara manual, dan akan menghasilkan suatu sistem informasi yang efisien dan mempunyai produktivitas tinggi.

Sistem pengelolaan keuangan di SMK Yafalah Ginggangtani masih menggunakan sistem konvensional yakni mencatat pada buku keuangan secara manual. SMK Yafalah Ginggangtani merupakan sekolah swasta yang berada dibawah naungan Yayasan Pendidikan Islam Alfalahiyah (YAFALAH). Setiap tahunnya SMK Yafalah Ginggangtani mengalami peningkatan prosentase peserta didik baru. Secara otomatis dengan semakin banyaknya peserta didik, maka bendahara akan semakin kesulitan dalam mengolah data keuangan yang masih bersifat manual tadi.

Pengelola keuangan SMK Yafalah menulis segala transaksi keuangan baik yang berupa pemasukan maupun pengeluaran di dalam buku-buku transaksi, seperti buku pemasukan dan pengeluaran harian, buku pembantu mata anggaran dan rekap bulanan siswa. Semua buku tersebut digunakan sebagai referensi dalam pembuatan laporan.

Dalam pengelolaan keuangan yang masih manual di SMK Yafalah ini, ditemukan berbagai masalah diantaranya, mudah hilang dan rusaknya data karena semua arsip laporan berupa buku-buku yang ditumpuk jadi satu, sulitnya proses pencarian data saat dibutuhkan, masih lamanya proses pelaporan data saat dibutuhkan, serta kurangnya tingkat keamanan data.

Tujuan dari penelitian, perancangan, dan pembuatan aplikasi pengelolaan keuangan ini adalah membuat sistem aplikasi pengelolaan keuangan dengan menggunakan visual basic 6.0 yang bertujuan untuk mengatasi permasalahan yang berkaitan dengan pengelolaan keuangan sekolah.

Berikut diagram alir kerangka berpikir penulis tentang pembuatan sistem aplikasi:

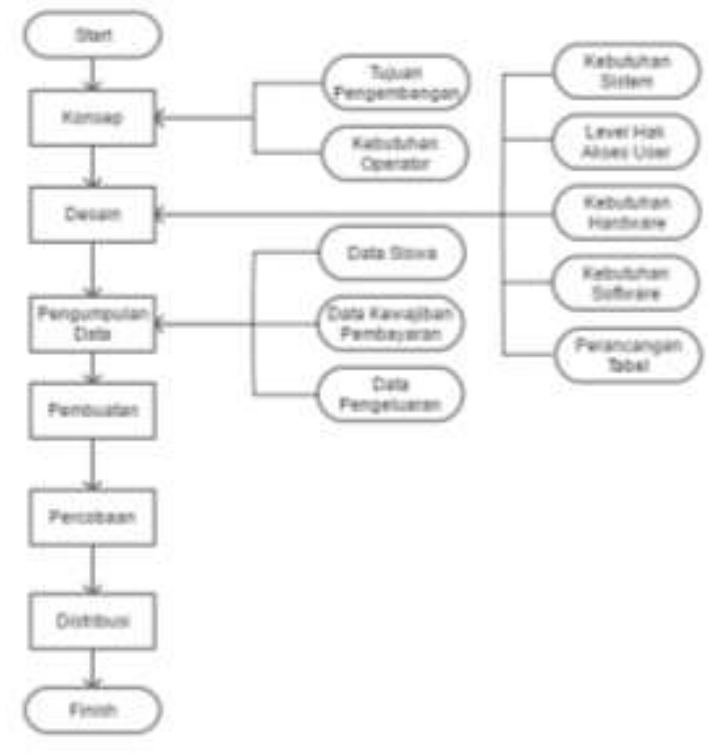

Gambar 2.1 Kerangka Berpikir

Sistem adalah kumpulan/group dari sub sistem/bagian/komponen apapun baik fisik ataupun non fisik yang saling 
berhubungan satu sama lain dan bekerja sama secara harmonis untuk mencapai satu tujuan tertentu.

Informasi adalah data yang diolah menjadi bentuk yang lebih berguna dan lebih berarti bagi penerimanya. Yang dimaksud dengan informasi adalah data yang diolah sehingga dapat dijadikan dasar-dasar untuk mengambil keputusan yang tepat.

Sistem informasi adalah "kombinasi antar prosedur kerja, informasi, orang dan teknologi informasi yang diorganisasikan untuk mencapai tujuan dalam sebuah organisasi.

Pengembangan sistem (system development) dapat berarti menyusun suatu sistem yang baru untuk menggantikan sistem yang lama secara keseluruhan atau memperbaiki sistem yang telah ada.

Data adalah kenyataan yang menggambarkan suatu kejadian nyata, data merupakan bentuk informasi yang masih mentah sehingga masih perlu diolah lebih lanjut agar menghasilkan keluaran yang bermanfaat.

Pengolahan data adalah waktu yang digunakan untuk menggambarkan perubahan bentuk data menjadi informasi yang memiliki kegunaan.

Visual basic 6.0 ialah bahasa pemrograman event-driven yang berasal dari BASIC. Event driven artinya program menunggu sampai adanya respons dari pemakai berupa kejadian tertentu, misalnya tombol diklik atau menu dipilih. Ketika event terdeteksi, event yang berhubungan akan melakukan aksi sesuai dengan kode yang diberikan.

Crystal Report 8.5 merupakan salah satu piranti lunak yang digunakan khusus untuk membuat laporan. Berbagai fasilitas yang dimilikinya memudahkan dalam pembuatan dan memperindah laporan yang dibutuhkan. Reporting tools berguna untuk membuat laporan dari sumber data yang sudah ada.
Menurut (Jogiyanto, 2005), dalam bukunya : "Analisis dan Desain Sistem Informasi", mengemukakan bahwa: Database merupakan kumpulan dari data yang saling berhubungan satu dengan yang lainnya, tersimpan diperangkat keras komputer dan digunakan perangkat lunak untuk memanipulasinya. Sedangkan dalam pembuatan aplikasi ini menggunakan microsoft access sebagai database nya.

\section{METODE PENELITIAN}

\section{A. Jenis Penelitian}

Penelitian ini merupakan jenis penelitian pengembangan (Research \& Development) yang berarti penelitian ini merupakan penelitian yang berorientasi pada produk. Produk yang dikembangkan dalam penelitian ini berupa sistem aplikasi keuangan.

Penelitian ini di laksanakan di SMK Yafalah Desa Ginggangtani Kecamatan Gubug Kabupaten Grobogan. Waktu penelitian ini dilaksanakan pada 01 Januari 2019 sampai selesai.

Model pengembangan sistem pengelolaan keuangan ini adalah serangkaian prosedur dalam rangka menghasilkan software keuangan sekolah yang bisa di kelola dengan baik untuk di jadikan laporan terhadap perkembangan keuangan sekolah. Model pengembangan yang digunakan adalah model pengembangan Luther (A.H. Sutopo, 2003). Pengembangan ini dilakukan dalam 6 tahap yaitu: konsep, perancangan, pengumpulan data, pembuatan, pecobaan, distribusi.

1. Konsep

Pada tahap ini adalah untuk menghasilkan sistem keuangan yang lebih akurat dan akuntable di bandingkan sistem keuangan sebelumnya. Memahami karakteristik pengguna, sehingga pada tahap ini perlu untuk menentukan secara khas siapa saja sesungguhnya pengguna 
yang kita layani dengan media yang kita kembangkan.

\section{Perancangan}

Tujuan dari tahap ini adalah membuat spesifikasi mendetail mengenai arsitektur proyek, gaya dan material untuk konsep. Spesifikasi dibuat secara detail sehingga tidak diperlukan keputusan baru, tetapi menggunakan apa yang sudah ditentukan dalam tahap ini.

Perancangan program dimulai dengan menyusun isi program, menentukan urutan penyajian dan menyusun alur penggunaan yang berupa flowchart.

\section{Pengumpulan Data}

Pengumpulan bahan dapat dikerjakan pararel dengan tahap pembuatan. Pada tahap ini dilakukan pengumpulan bahan seperti data siswa, data kewajiban pembayaran siswa, dan data pengeluaran sekolah. Sehingga pembuat aplikasi bisa tau output yang dibutuhkan sekolah.

\section{Pembuatan}

Tahap ini adalah tahap dibuatnya semua media. Pembuatan aplikasi berdasarkan struktur navigasi dan storyboard atau diagram objek yang berasal dari tahap perencanaan.

\section{Percobaan}

Pengujian dilakukan setelah menyelesaikan tahap pembuatan dengan menjalankan aplikasi dan melihat apakah terdapat error atau kesalahan dalam program pengelolaan keuangan sekolah yang dibuat.

Dalam tahap percobaan ada 3 pihak penilai diantaranya: 1). Ahli aplikasi. Penilaian aplikasi keuangan oleh ahli aplikasi meliputi interface dan fungsionalitas sistem karena sangat berkaitan dengan fungsional dan interaktif aplikasi pengelolaan keuangan yang dikembangkan. Penilaian aplikasi pengelolaan keuangan dilakukan dengan mengacu pada instrumen pengujian kualitas program tersebut. Diperoleh data
I untuk dianalisis dan merevisi aplikasi keuangan. 2). Ahli materi. Ahli materi yang menilai aplikasi keuangan sekolah ini adalah kepala sekolah di SMK Yafalah Ginggangtani. Penilaian aplikasi keuangan oleh ahli materi meliputi aspek kelancaran dan berfungsinya program keuangan dengan baik atau tidak. 3). Responden. Pengujian responden dilakukan oleh bendahara, guru, dan staff TU di SMK Yafalah Ginggangtani. Penilaian aplikasi keuangan ini meliputi interface, aspek isi, aspek keakuratan. Penilaian aplikasi keuangan sekolah ini dilakukan dengan menggunakan lembar print out dengan model penilian 5 skala.

6. Distribusi

Setelah dilakukan pengujian aplikasi keuangan sekolah, maka dilakukan tahap pemasangan. Pada tahap ini, aplikasi keuangan sekolah di install dan disimpan dalam sebuah komputer yang sudah dilakukan setting sebelumnya, sehingga aplikasi bisa berjalan dengan baik. Setelah dilakukan penerapan aplikasi keuangan, selanjutnya akan di serahkan ke admin.

\section{B. Validasi Sistem}

Proses validasi sistem menggunakan dua tahap, yaitu:

1). Aspek functionality untuk menguji validasi fungsionalitas dari perangkat lunak agar fungsi yang berjalan sesuai dengan hasil yang diharapkan. Validasi ini akan dilakukan oleh ahli aplikasi yaitu Bapak Afis Pratama, S.T,M.Pd. selaku dosen di Universitas Ivet dan seorang ahli materi yaitu Bapak Yazid S.H, S.E. selaku kepala sekolah di SMK Yafalah Ginggangtani.

Tabel 3.6 Instrumen Functionality

\begin{tabular}{|c|c|l|c|c|}
\hline NO & $\begin{array}{c}\text { Fung } \\
\text { si }\end{array}$ & \multicolumn{1}{|c|}{ Pernyataan } & Ya & Tidak \\
\hline 1 & $\begin{array}{l}\text { Navig } \\
\text { asi }\end{array}$ & $\begin{array}{l}\text { Fungsi navigasi } \\
\text { utama sudah } \\
\text { berfungsi dengan } \\
\text { baik }\end{array}$ & & \\
\hline
\end{tabular}




\begin{tabular}{|c|c|c|}
\hline 2 & Login & $\begin{array}{l}\text { Fungsi untuk login } \\
\text { sudah berfungsi } \\
\text { dengan baik }\end{array}$ \\
\hline 3 & $\begin{array}{l}\text { Logou } \\
t\end{array}$ & $\begin{array}{l}\text { Fungsi untuk } \\
\text { logout sudah } \\
\text { berfungsi dengan } \\
\text { baik }\end{array}$ \\
\hline 4 & $\begin{array}{l}\text { Ganti } \\
\text { passw } \\
\text { ord }\end{array}$ & $\begin{array}{l}\text { Fungsi untuk } \\
\text { mengganti } \\
\text { password pengguna } \\
\text { sudah berfungsi } \\
\text { dengan baik }\end{array}$ \\
\hline 5 & $\begin{array}{l}\text { Data } \\
\text { siswa }\end{array}$ & $\begin{array}{l}\text { Fungsi untuk } \\
\text { menambah, } \\
\text { mengubah, } \\
\text { menghapus, dan } \\
\text { pencarian data } \\
\text { siswa sudah } \\
\text { berfungsi dengan } \\
\text { baik }\end{array}$ \\
\hline 6 & $\begin{array}{l}\text { Data } \\
\text { wajib } \\
\text { pemba } \\
\text { yaran }\end{array}$ & $\begin{array}{l}\text { Fungsi untuk } \\
\text { menambah, } \\
\text { mengubah, } \\
\text { menghapus, dan } \\
\text { pencarian data } \\
\text { wajib pembayaran } \\
\text { sudah berfungsi } \\
\text { dengan baik }\end{array}$ \\
\hline 7 & $\begin{array}{l}\text { Data } \\
\text { pemba } \\
\text { yaran }\end{array}$ & $\begin{array}{l}\text { Fungsi Untuk } \\
\text { menambah, } \\
\text { mengubah, dan } \\
\text { menghapus data } \\
\text { pembayaran siswa } \\
\text { sudah berfungsi } \\
\text { dengan baik }\end{array}$ \\
\hline 8 & $\begin{array}{l}\text { Data } \\
\text { pengel } \\
\text { uaran }\end{array}$ & $\begin{array}{l}\text { Fungsi Untuk } \\
\text { menambah, } \\
\text { mengubah, } \\
\text { menghapus, dan } \\
\text { pencarian data } \\
\text { pengeluaran } \\
\text { sekolah sudah } \\
\text { berfungsi dengan } \\
\text { baik }\end{array}$ \\
\hline 9 & $\begin{array}{l}\text { Data } \\
\text { Lapor } \\
\text { an }\end{array}$ & $\begin{array}{l}\text { Fungsi untuk } \\
\text { mencetak data } \\
\text { pemasukan, data } \\
\text { pengeluaran, dan }\end{array}$ \\
\hline
\end{tabular}

\begin{tabular}{|l|l|l|l|}
\hline & $\begin{array}{l}\text { data tunggakan } \\
\text { siswa sudah } \\
\text { berfungsi dengan } \\
\text { baik }\end{array}$ & & \\
\hline
\end{tabular}

2). Aspek usability untuk menguji akan dilakukan dengan menggunakan skala Likert dengan 5 pilihan yang akan diisi oleh bendahara, staff TU, dan guru di SMK Yafalah Ginggangtani.

Tabel 3.7 Instrumen Usability

\begin{tabular}{|c|c|c|c|c|c|c|}
\hline No & Pernyataan & \multicolumn{5}{|c|}{ Skala } \\
\hline 1. & $\begin{array}{l}\text { Secara keseluruhan, saya } \\
\text { puas dengan kemudahan } \\
\text { pemakaian aplikasi ini. }\end{array}$ & 1 & 2 & 3 & 4 & 5 \\
\hline 2. & $\begin{array}{l}\text { Penggunaan aplikasi ini } \\
\text { sangat simpel/ sederhana. }\end{array}$ & 1 & 2 & 3 & 4 & 5 \\
\hline 3. & $\begin{array}{l}\text { Saya dapat menyelesaikan } \\
\text { pekerjaan dengan sempurna } \\
\text { menggunakan aplikasi ini. }\end{array}$ & 1 & 2 & 3 & 4 & 5 \\
\hline 4. & $\begin{array}{l}\text { Saya dapat menyelesaikan } \\
\text { pekerjaan saya dengan } \\
\text { cepat menggunakan aplikasi } \\
\text { ini. }\end{array}$ & 1 & 2 & 3 & 4 & 5 \\
\hline 5. & $\begin{array}{l}\text { Saya dapat menyelesaikan } \\
\text { pekerjaan saya secara } \\
\text { efisien menggunakan } \\
\text { aplikasi ini. }\end{array}$ & 1 & 2 & 3 & 4 & 5 \\
\hline 6. & $\begin{array}{l}\text { Saya merasa nyaman } \\
\text { menggunakan aplikasi ini. }\end{array}$ & 1 & 2 & 3 & 4 & 5 \\
\hline 7. & $\begin{array}{l}\text { Sangat mudah mempelajari } \\
\text { penggunaan aplikasi ini. }\end{array}$ & 1 & 2 & 3 & 4 & 5 \\
\hline 8. & $\begin{array}{l}\text { Saya yakin akan lebih } \\
\text { produktif ketika } \\
\text { menggunakan aplikasi ini. }\end{array}$ & 1 & 2 & 3 & 4 & 5 \\
\hline 9. & $\begin{array}{l}\text { Pesan kesalahan yang } \\
\text { diberikan aplikasi ini } \\
\text { menjelaskan dengan jelas } \\
\text { cara mengatasinya. }\end{array}$ & 1 & 2 & 3 & 4 & 5 \\
\hline 10. & $\begin{array}{l}\text { Kapanpun saya membuat } \\
\text { kesalahan, saya bisa } \\
\text { memperbaikinya dengan } \\
\text { cepat dan mudah. }\end{array}$ & 1 & 2 & 3 & 4 & 5 \\
\hline 11. & $\begin{array}{l}\text { Informasi yang disediakan } \\
\text { aplikasi ini cukup jelas. }\end{array}$ & 1 & 2 & 3 & 4 & 5 \\
\hline
\end{tabular}




\begin{tabular}{|l|l|l|l|l|l|l|}
\hline 12. & $\begin{array}{l}\text { Sangat mudah mencari } \\
\text { informasi yang dibutuhkan } \\
\text { di aplikasi ini. }\end{array}$ & 1 & 2 & 3 & 4 & 5 \\
\hline 13. & $\begin{array}{l}\text { Informasi yang disediakan } \\
\text { aplikasi sangat mudah } \\
\text { dipahami. }\end{array}$ & 1 & 2 & 3 & 4 & 5 \\
\hline 14. & $\begin{array}{l}\text { Informasi yang disediakan } \\
\text { efektif membantu } \\
\text { menyelesaikan tugas. }\end{array}$ & 1 & 2 & 3 & 4 & 5 \\
\hline 15. & $\begin{array}{l}\text { Tata letak informasi yang } \\
\text { ditampilkan di layar } \\
\text { aplikasi sangat jelas. }\end{array}$ & 1 & 2 & 3 & 4 & 5 \\
\hline 16. & $\begin{array}{l}\text { Tampilan/ antarmuka } \\
\text { aplikasi menyenangkan. }\end{array}$ & 1 & 2 & 3 & 4 & 5 \\
\hline 17. & $\begin{array}{l}\text { Saya suka menggunakan } \\
\text { tampilan aplikasi seperti ini. }\end{array}$ & 1 & 2 & 3 & 4 & 5 \\
\hline 18. & $\begin{array}{l}\text { Aplikasi ini memiliki fungsi } \\
\text { dan kemampuan } \\
\text { (kapabilitas) sesuai harapan } \\
\text { saya. }\end{array}$ & 1 & 2 & 3 & 4 & 5 \\
\hline 19. & $\begin{array}{l}\text { Secara keseluruhan, saya } \\
\text { puas dengan aplikasi ini. }\end{array}$ & 1 & 2 & 3 & 4 & 5 \\
\hline
\end{tabular}

III. HASIL DAN PEMBAHASAN

A. Deskripsi Penelitian

Pada tahap pengembangan sistem ini menggunakan 6 tahap pengembangan sesuai metode Luther yaitu:

\section{Konsep}

Konsep pembuatan sistem aplikasi keuangan yang baru di SMK Yafalah Ginggangtani adalah mengatasi segala permasalahan yang ada pada sistem keuangan yang lama. Berikut permasalahan yang sudah diidentifikasikan dalam penelitian ini yaitu laporan pembayaran siswa, pengeluaran sekolah, dan laporan kekurangan pembayaran siswa kepada orang tua. Orang tua mengalami kesulitan dalam mengingat dan menghitung kekurangan administrasi putra putrinya selama satu semester. Dikarenakan sering kali orang tua atau wali murid melakukan pembayaran dengan metode cicilan. Terlebih lagi buku SOP siswa hanya mencatat pembayaran siswa, tetapi tidak menyertakan berapa kekurangan siswa dari setiap pembayaran tersebut. Sering kali buku pembayaran SOP rusak, dan dihilangkan peserta didik.

Bendahara dalam memberikan laporan keuangan kepada kepala sekolah juga masih dengan cara manual, laporan pemasukan dan pengeluaran sekolah dibuat oleh bendahara kepada kepala sekolah secara tertulis. Selain itu bendahara selalu kerepotan dalam membuatkan laporan pembayaran peserta didik kepada orang tua atau wali murid tiap semester.

\section{Desain}

Pada tahap desain ini yang dilakukan adalah membuat desain experience dan interface. Pada pembuatan desain experience dilakukan dengan UML sebagai bahasa permodelannya. Pembuatan UML diagram menggunakan bantuan software pencil. Berikut flowchart diagram alir program:

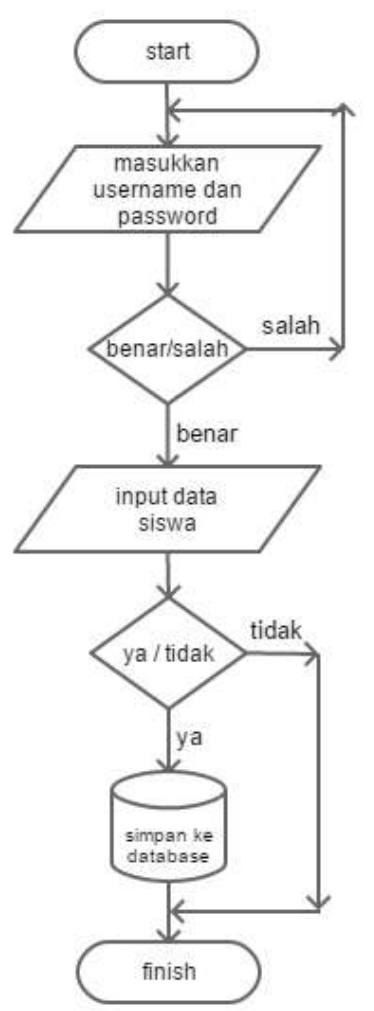

Gambar 4.1 Flowchart input data siswa 


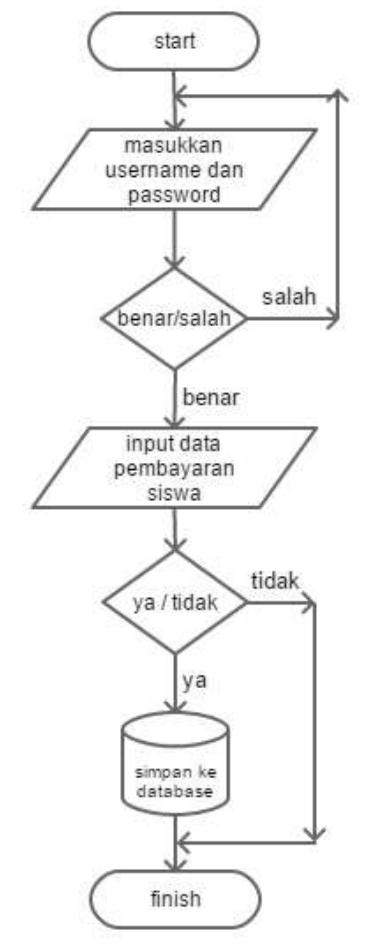

Gambar 4.2 Flowchart input data wajib bayar

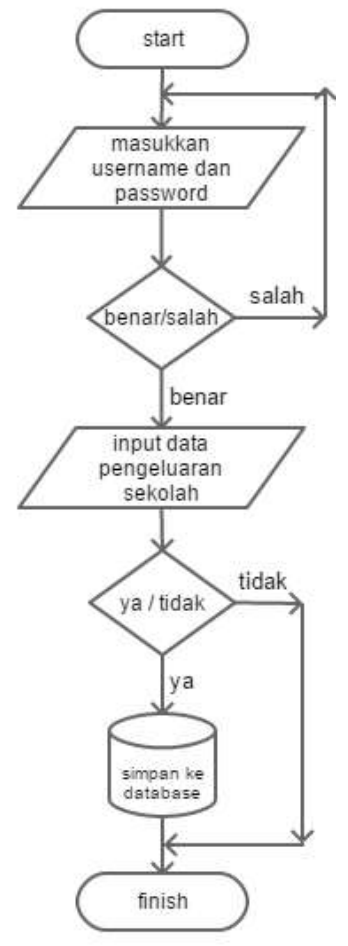

Gambar 4.3 Flowchart input data pembayaran

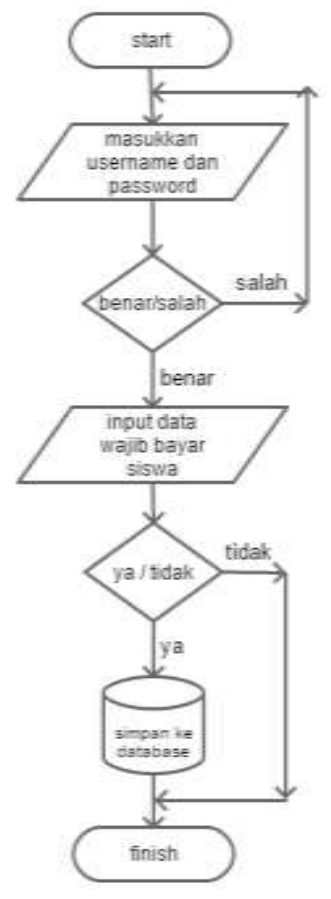

Gambar 4.4 Flowchart input data pengeluaran

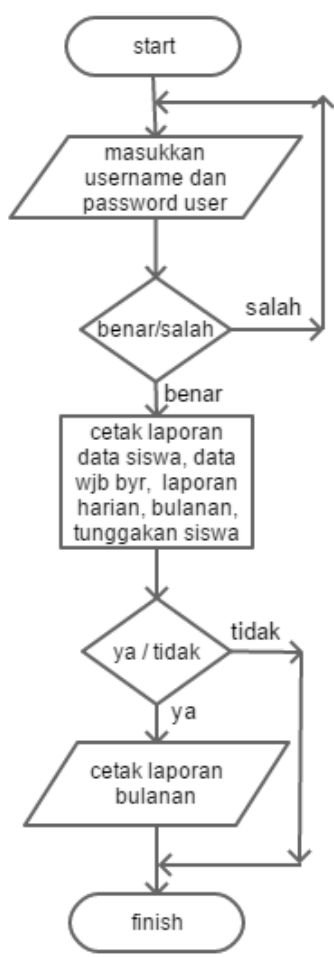

Gambar 4.6 Flowchart cetak laporan user 


\section{Pengumpulan Data}

Berdasarakan penelitian di SMK Yafalah Ginggangtani, diperoleh data-data pokok yang digunakan dalam pembuatan sistem aplikasi yang baru. Data tersebut disimpan dalam database Ms. Access dengan nama database keuangan.mdb. dalam database tersebut dibuat beberapa tabel dengan nama: 1). Tb_login. 2). Tb_siswa. 3). Tb_wjb_byr. 4). Tb_pmbyrn. 5). Tb_pengeluaran.

4. Pembuatan

Tahap selanjutnya adalah pembuatan aplikasi. Berikut desain interface hasil pembuatan aplikasi sistem pengelolaan keuangan yang baru:

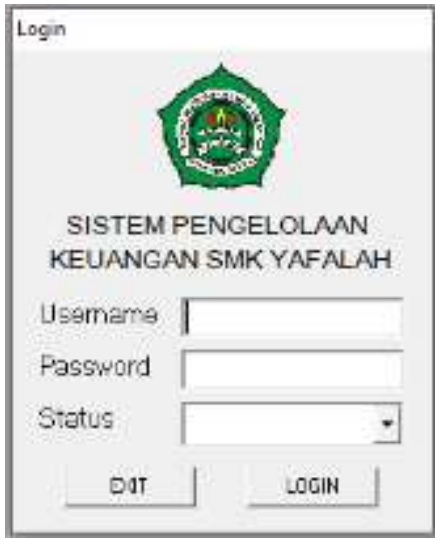

Gambar desain interface login

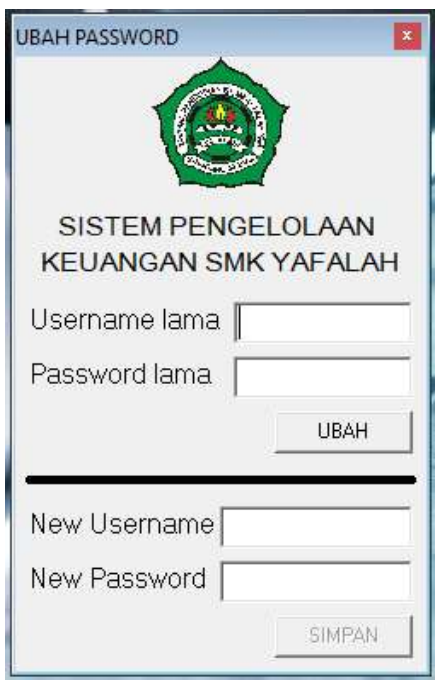

Gambar desain interface change password

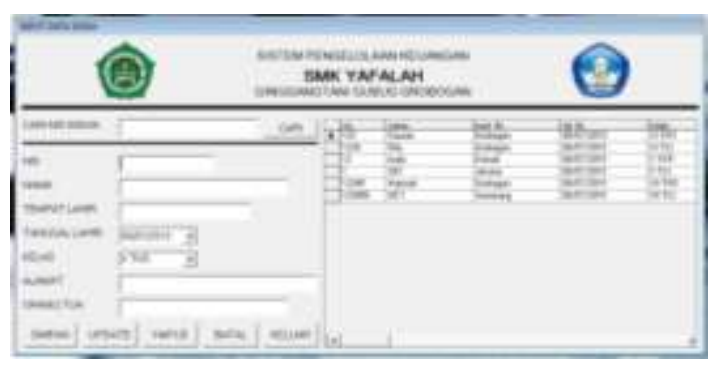

Gambar desain interface input data siswa

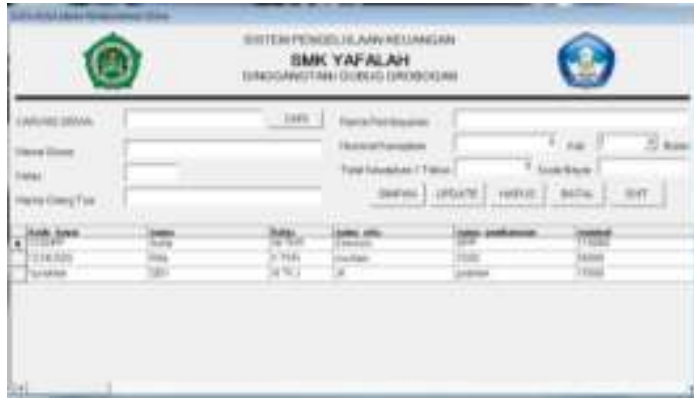

Gambar desain interface input data wajib bayar siswa

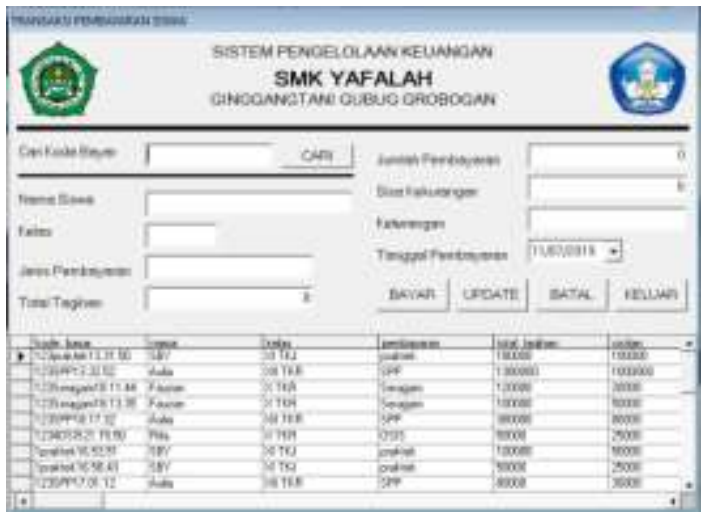

Gambar desain interface input data pembayaran siswa

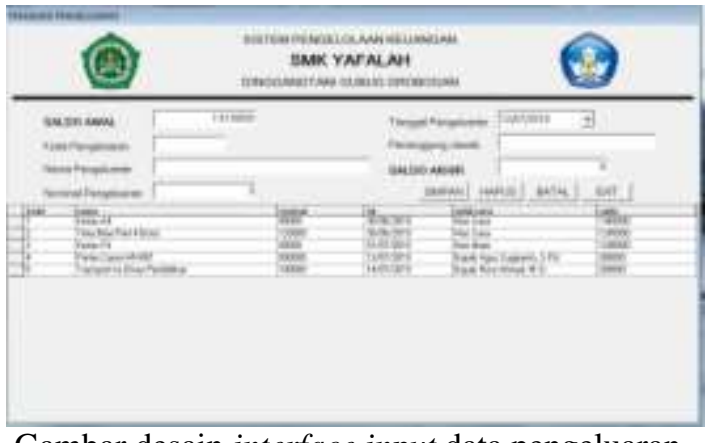

Gambar desain interface input data pengeluaran sekolah 


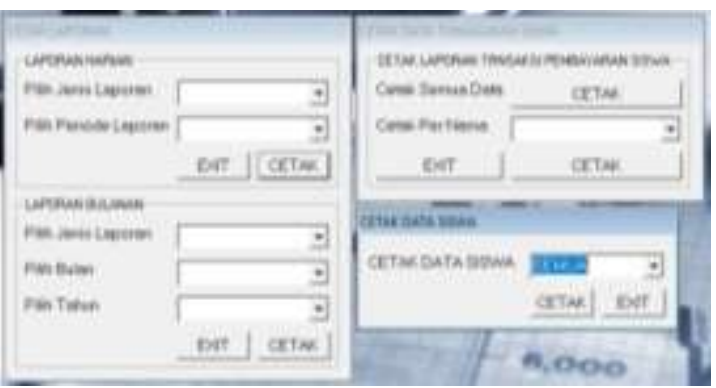

Gambar desain interface menu cetak laporan

\section{Testing}

Proses testing dilakukan oleh ahli aplikasi yaitu Bapak Afis Pratama, S.T. M.Pd. selaku dosen Universitas Ivet. Selanjutnya dilakukan uji coba oleh ahli materi yaitu Bapak Yazid S.H., S.E. selaku kepala sekolah di SMK Yafalah Ginggangtani, dan juga aplikasi diuji coba oleh bendahara sekolah, pihak staff TU dan Guru ikut melakukan testing pada aplikasi, yang nanti dari pihak staff TU atau Guru dapat melakukan cetak data mengunakan akun user.

\section{Implementasi/distribusi}

Berikut hasil dari proses implementasi sistem:

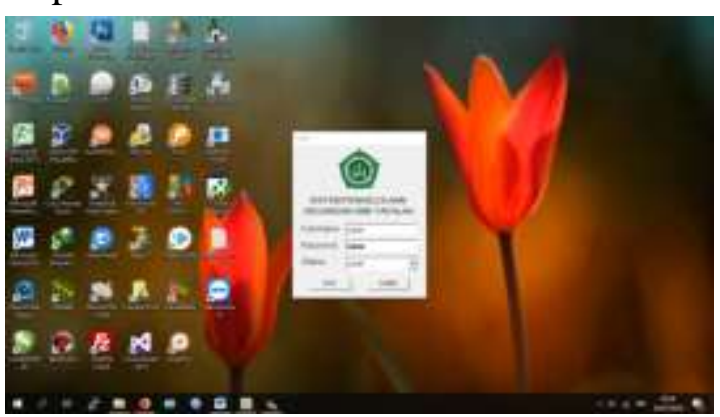

Gambar 4.14 Halaman login user

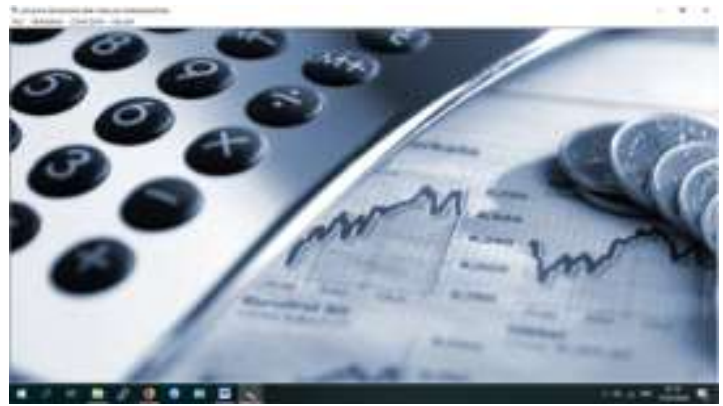

Gambar 4.15 Halaman utama admin

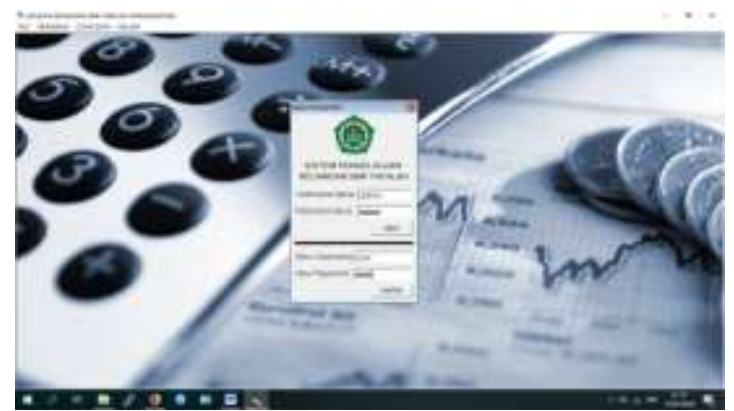

Gambar 4.17 Halaman rubah username dan password

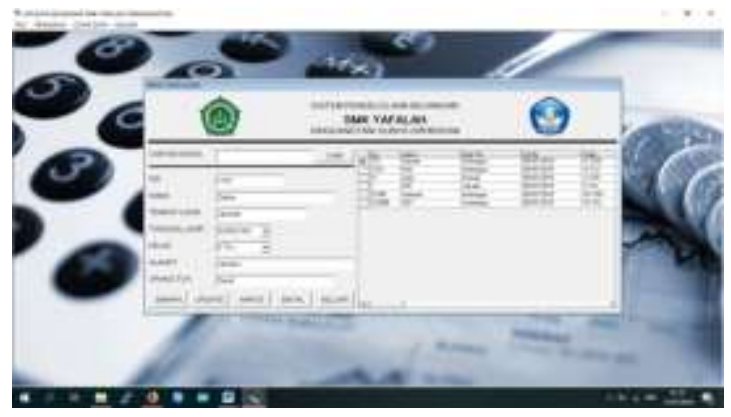

Gambar 4.18 Halaman input data siswa

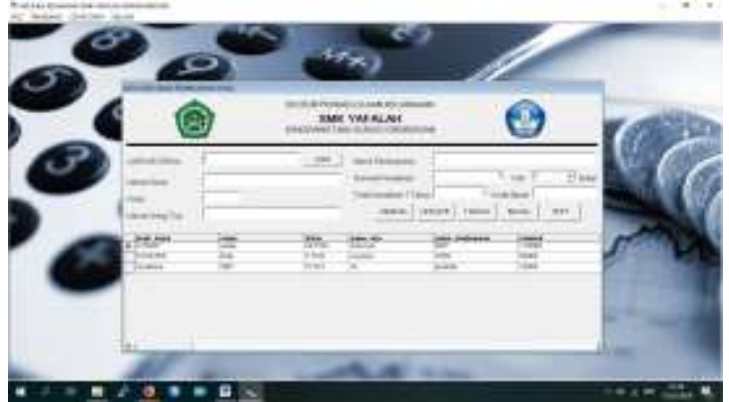

Gambar 4.19 Halaman input data kewajiban pembayaran siswa

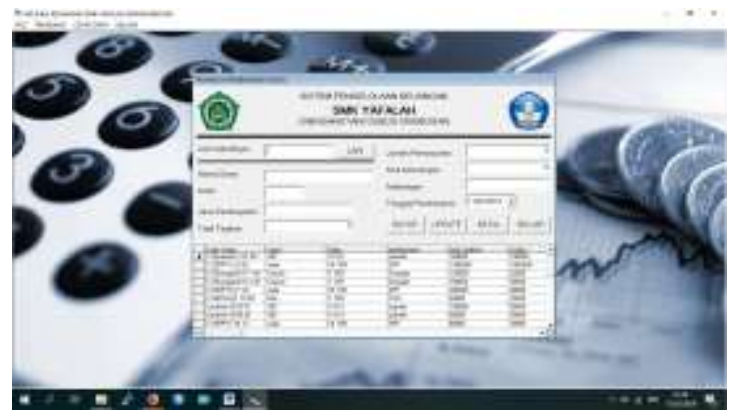

Gambar 4.20 Halaman pembayaran siswa 


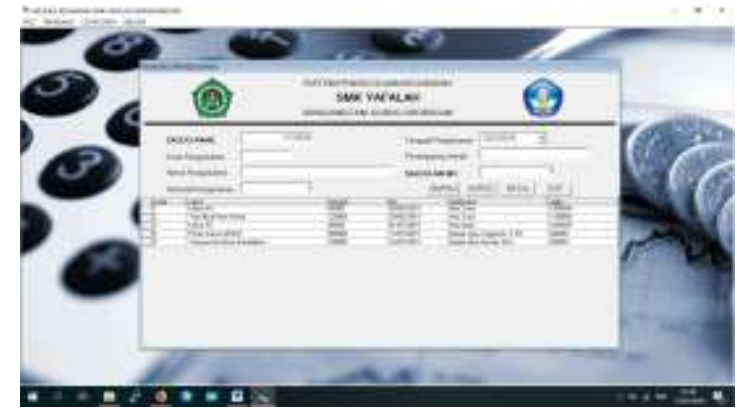

Gambar 4.21 Halaman transaksi pengeluaran sekolah

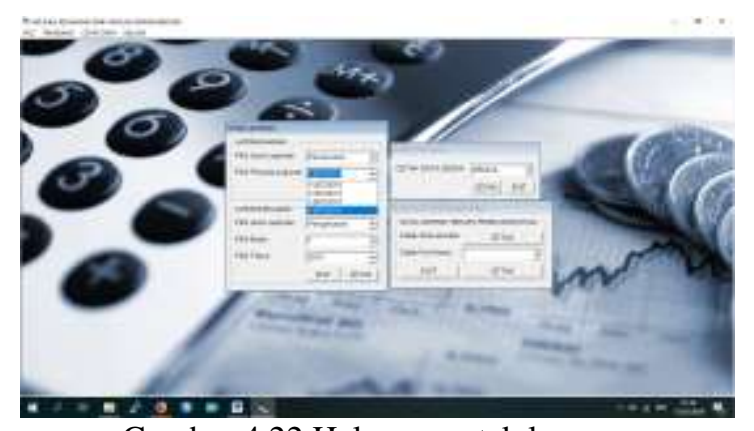

Gambar 4.22 Halaman cetak laporan

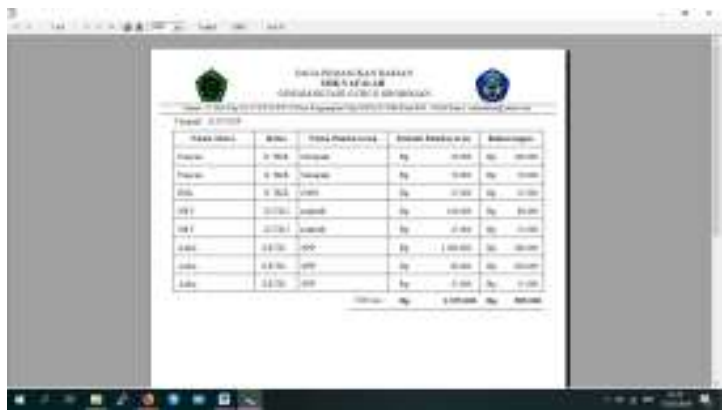

Gambar 4.23 Halaman hasil cetak laporan

B. Hasil Penelitian

1. Pengujian functionality

Pengujian functionality diujikan pada satu orang ahli aplikasi, dan satu ahli materi di SMK Yafalah Ginggangtani. Pada lembar validasi ahli aplikasi dan ahli materi, jawaban setiap item pertanyaan menggunakan skala Guttman. Setiap fungsi yang berjalan dengan baik maka penguji akan memberikan checklist pada tab Ya, bila fungsi tidak berjalan dengan baik maka penguji akan memberikan checklist pada tab Tidak, dengan ketentuan Ya bernilai satu sedangkan jawaban Tidak bernilai nol.
Presentase skor total $=\frac{\text { jumlah jawaban }}{\text { skor } \text { maksimal }} \times 100 \%$

Menurut (Agung, A. A. Gede. 2010:58) untuk dapat memberikan makna dan dalam pengambilan keputusan digunakan ketetapan sebagai berikut:

Tabel 4.2 Konversi tingkat pencapaian dengan skala 5

\begin{tabular}{|c|c|}
\hline $\begin{array}{c}\text { Tingkat } \\
\text { Pencapaian } \\
(\mathbf{\%})\end{array}$ & Kualifikasi \\
\hline $90-100$ & Sangat baik \\
\hline $80-89$ & Baik \\
\hline $65-79$ & Cukup \\
\hline $55-64$ & Kurang \\
\hline $0-54$ & Sangat kurang \\
\hline
\end{tabular}

Tabel 4.3 Hasil pengujian functionality

\begin{tabular}{|c|c|c|c|c|}
\hline \multirow{2}{*}{$\begin{array}{c}\text { No } \\
\text { Pertany } \\
\text { aan }\end{array}$} & \multirow{2}{*}{$\begin{array}{c}\text { Jawaba } \\
n\end{array}$} & \multicolumn{2}{|c|}{ Skor oleh validator } & \multirow[b]{2}{*}{ Hasil } \\
\hline & & $\begin{array}{c}\text { Validat } \\
\text { or } 1\end{array}$ & $\begin{array}{c}\text { Validat } \\
\text { or } 2\end{array}$ & \\
\hline \multirow{2}{*}{1} & $\mathrm{Ya}$ & 1 & 1 & 2 \\
\hline & Tidak & 0 & 0 & 0 \\
\hline \multirow{2}{*}{2} & $\mathrm{Ya}$ & 1 & 1 & 2 \\
\hline & Tidak & 0 & 0 & 0 \\
\hline \multirow{2}{*}{3} & $\mathrm{Ya}$ & 1 & 1 & 2 \\
\hline & Tidak & 0 & 0 & 0 \\
\hline \multirow{2}{*}{4} & $\mathrm{Ya}$ & 1 & 1 & 2 \\
\hline & Tidak & 0 & 0 & 0 \\
\hline \multirow{2}{*}{5} & $\mathrm{Ya}$ & 1 & 1 & 2 \\
\hline & Tidak & 0 & 0 & 0 \\
\hline \multirow{2}{*}{6} & $\mathrm{Ya}$ & 1 & 1 & 2 \\
\hline & Tidak & 0 & 0 & 0 \\
\hline \multirow{2}{*}{7} & $\mathrm{Ya}$ & 1 & 1 & 2 \\
\hline & Tidak & 0 & 0 & 0 \\
\hline \multirow{2}{*}{8} & $\mathrm{Ya}$ & 1 & 1 & 2 \\
\hline & Tidak & 0 & 0 & 0 \\
\hline \multirow{4}{*}{9} & $\mathrm{Ya}$ & 1 & 1 & 2 \\
\hline & Tidak & 0 & 0 & 0 \\
\hline & $\mathrm{Ya}$ & 1 & 1 & 2 \\
\hline & Tidak & 0 & 0 & 0 \\
\hline \multicolumn{4}{|c|}{ Skor Maksimal } & 18 \\
\hline
\end{tabular}

Berdasarkan hasil validasi ahli aplikasi dan ahli materi, prosentase skor dapat dihitung:

Presentase skor total $=\frac{\text { jumlah jawaban } Y a}{\text { skor } \text { maksimal }} \times 100 \%$

Presentase skor total $=\frac{18}{18} \times 100 \%=100 \%$

Persentase hasil pengujian functionality adalah 100\%. Hasil pengujian functionality ini kemudian 
dikonversikan kedalam tingkat pencapaian skala 5 sehingga didapat hasil "sangat baik" dan memenuhi aspek functionality.

\section{Pengujian usability}

Pengujian aspek usability menggunakan instrumen berupa angket yang dikembangkan oleh IBM. Hasil dari pengujian aspek usability sistem informasi pengelolaan keuangan di SMK Yafalah Ginggangtani ditunjukan pada tabel.

Tabel 4.4 Hasil pengujian aspek usability

\begin{tabular}{|c|c|c|c|c|c|}
\hline Pernyataan & STS & TS & RR & S & SS \\
\hline 1 & 0 & 0 & 1 & 4 & 5 \\
\hline 2 & 0 & 0 & 2 & 2 & 6 \\
\hline 3 & 0 & 0 & 2 & 6 & 2 \\
\hline 4 & 0 & 0 & 1 & 8 & 1 \\
\hline 5 & 0 & 0 & 0 & 9 & 1 \\
\hline 6 & 0 & 0 & 4 & 4 & 2 \\
\hline 7 & 0 & 0 & 0 & 4 & 6 \\
\hline 8 & 0 & 0 & 0 & 3 & 7 \\
\hline 9 & 0 & 0 & 2 & 3 & 5 \\
\hline 10 & 0 & 0 & 2 & 4 & 4 \\
\hline 11 & 0 & 0 & 2 & 7 & 1 \\
\hline 12 & 0 & 0 & 0 & 1 & 9 \\
\hline 13 & 0 & 0 & 0 & 8 & 2 \\
\hline 14 & 0 & 0 & 0 & 10 & 0 \\
\hline 15 & 0 & 0 & 0 & 8 & 2 \\
\hline 16 & 0 & 0 & 2 & 5 & 3 \\
\hline 17 & 0 & 0 & 4 & 6 & 0 \\
\hline 18 & 0 & 0 & 3 & 6 & 1 \\
\hline 19 & 0 & 0 & 4 & 2 & 4 \\
\hline Total & $\mathbf{0}$ & $\mathbf{0}$ & $\mathbf{2 9}$ & $\mathbf{1 0 0}$ & $\mathbf{6 1}$ \\
\hline
\end{tabular}

Tabel 4.5 Perhitungan total skor

\begin{tabular}{|c|c|c|c|}
\hline & Jumlah & Skor & $\begin{array}{c}\text { Jumlah } \mathbf{x} \\
\text { Skor }\end{array}$ \\
\hline STS & 0 & 1 & 0 \\
\hline TS & 0 & 2 & 0 \\
\hline RR & 29 & 3 & 87 \\
\hline S & 100 & 4 & 400 \\
\hline SS & 61 & 5 & 305 \\
\hline \multicolumn{4}{|c|}{ Skor Total } \\
\hline
\end{tabular}

Persentase skor total dapat dihitung menggunakan rumus :

Persentase skor total $=\frac{\text { Jumlah Skor Total }}{\text { Skor Maksimal }} \times 100$

Skor maksimal adalah jika semua responden menjawab "Sangat Setuju"
(SS) dengan skor 5. Sehingga skor maksimal dapat dihitung :

Skor maksimal $=$ total responden $\mathrm{x}$ jumlah pernyataan $\mathrm{x} 5$

$$
\begin{aligned}
& =10 \times 19 \times 5 \\
& =950 \\
\text { Presentase skor total } & =\frac{792}{950} \times 100 \% \\
& =83,37 \%
\end{aligned}
$$

Persentase hasil pengujian usability adalah $83,37 \%$. Hasil pengujian ini kemudian dikonversikan kedalam skala kualitatif sehingga didapat hasil "baik" dan memenuhi aspek usability.

\section{PENUTUP}

Berdasarkan hasil penelitian dan pembahasan yang telah dilakukan mengenai pengembangan sistem pengelolaan keuang di SMK Yafalah Ginggangtani, maka dapat diambil beberapa kesimpulan sebagai berikut: 1). Aplikasi pengelolaan keuangan pada SMK Yafalah Ginggangtani dibuat menggunakan aplikasi visual basic 6.0 dengan cetak laporan menggunakan aplikasi crystal report 8.5. Model yang digunakan yaitu tahap requirements, specification, design, dan implementation. 2). Pengujian kualitas aplikasi diuji menggunakan standar ISO 9001 melalui tahapan unit testing, integration testing, system testing, dan acceptance testing. Pada tahap acceptance testing melalui beberapa aspek yaitu functional suitability, performance efficiency.

\section{DAFTAR PUSTAKA}

Agung, A. A. Gede. 2010. Evaluasi Pendidikan. Singaraja: Undiksha.

Al-Bahra Bin Ladjamudin. 2005. Desain Informasi. Jakarta: Erlangga.

Baswananda, Aji Raino. 2014. Sistem Pembayaran SPP Berbasis Komputer pada SMK Kesatrian 1 Semarang. Semarang: Aji Raino Baswananda. 
Heriyanto. 2005. Rekayasa Sistem Berorientasi Objek. Yogyakarta: Andi Offset.

Hutahaean, Jeperson. 2014. Konsep Sistem Informasi, Yogyakarta: deepublish.

Jogiyanto H.M. 2005. Analisis dan Desain Sistem Informasi. Yogyakarta: Andi Offset.

Jogiyanto H.M. 2005. Sistem Teknologi Informasi. Yogyakarta: Andi.

Kadir, Abdul. 2003. Pengenalan Sistem Informasi. Yogyakarta: Andi.

Kristanto. 2005. Perancangan Aplikasi dan Sistem Informasi. Jakarta: Andi Offset.

Lilis Tamba, Mayer. 2017. Perancangan Sistem Informasi Pembayaran SPP pada Sekolah Dasar Cerdas Ceria Sungai Daun Batam. Batam: Mayer Lilis Tamba.

Miles, M.B. \& Huberman, M. 2012. Analisis Data. Jakarta: Penerbit Universitas Indonesia.

Moleong, Lexy J. 2014. Metodologi Penelitian Kualitatif. Bandung: PT Remaja Rosdakarya.

Mulyadi, 2010. Sistem Informasi Akuntansi. Jakarta: Salemba Empat.

Mulyanto, Agus. 2009. Sistem Informasi Konsep dan Aplikasi. Yogyakarta: Pustaka Pelajar.

Nazir, Moh. 2014. Metode Penelitian. Bogor: Ghalia Indonesia.

Sholikhah, Zaimatus. 2014. Pengembangan dan Analisis Sistem Informasi Keuangan Komite SMK Negeri 1 Klaten. Klaten: Zaimatus Sholikhah.

Sugiyono. 2016. Metode penelitian kuantitatif, kualitatif dan $R \& D$. Bandung: Alfabeta.

Susanto, Azhar. 2013. Sistem Informasi Akuntansi. Jakarta: Gramedia.

Sutarman. 2012. Buku Pengantar Teknologi Informasi. Jakarta: Bumi Aksara.
Sutopo, A. H. 2003. Multimedia Interaktif dengan Flash. Yogyakarta: Graha Ilmu.

Tantra, Rudy. 2012. Manajemen Proyek Sistem Informasi. Yogyakarta: Andi.

Tegeh, I Made \& I Made Kirna. 2010. Metode Penelitian Pengembangan Pendidikan. Singaraja: Universitas Pendidikan Ganesha.

Winarno, Wing wahyu. 2006. Sistem Informasi Akuntansi. Yogyakarta: UPP STIM YKPN. 